\title{
Measurement of radon concentrations for some houses in Al-Najaf city /Iraq
}

\author{
Ali A.Al-Hamidawi ${ }^{1}$, Hussein M. Nasir ${ }^{1}$, Asia H. Al.Mashhadani ${ }^{2}$, \\ Abdulhussan A. Al. Bayati ${ }^{2}$ \\ ${ }^{1}$ Department of Physics, College of Science, University of Al-Kufa \\ ${ }^{2}$ Department of Physics, College of Science, University of Baghdad
}

E-mail: aliabojassem@yahoo.com

\begin{abstract}
Measurement of radon concentration level was carried out in 40 houses in Al - Najaf city during summer season of 2012. Long term measurement of indoor of old building radon concentrations have been taken, using a previously calibrated passive diffusion dosimeters containing CR - 39 solid state nuclear track detectors which are very sensitive for alpha particles. The measurement of the indoor radon concentration obtained in summer in these regions ranged from $11.654 \pm 4.216 \mathrm{~Bq} \cdot \mathrm{m}^{-3}$ to $53.610 \pm 8.777 \mathrm{~Bq} \cdot \mathrm{m}^{-3}$. The results were within universally permitted levels.
\end{abstract}

Key words

CR-39 plastic nuclear

track detectors,

Radon - 222

concentration levels, CR-39 detector.

Article info.

Received: Nov. 2012

Accepted: Jun. 2013

Published: Dec. 2013

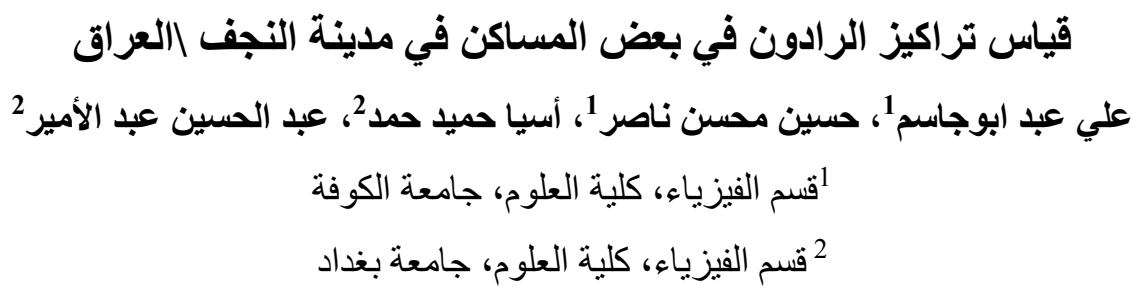

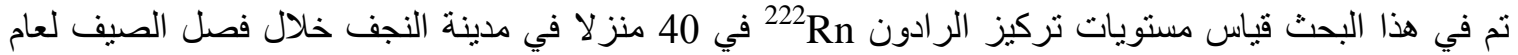

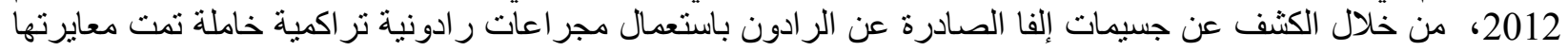

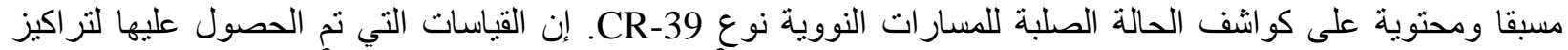

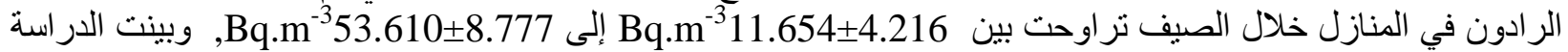

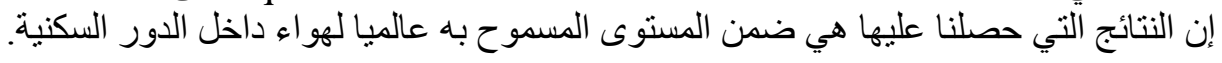

\section{Introduction}

Although there are several different isotopes of radon, the one that is of greatest concern as a potential human health threat is Radon Rn-222. $\mathrm{Rn}-222$ gas is formed naturally during a chain of radioactive disintegrations. The decay series begins when uranium-238 decays; uranium is widely distributed in rocks and soil throughout the earth's crust, with half-life of
4.5 billion years, which means a very slow disintegration. Because Rn-222 is a gas, it moves freely in the air spaces between rocks and in soil. It becomes a human health concern when it leaks from the underlying soil into houses and other buildings. If it builds up to high concentrations in indoor air, radon and its decay products where inhaled and cause lung cancer. Some 
amounts of radon can enter the buildings from the construction materials itself and some can also be carried in by the water supply, cannot escape back to the outside because of restricted ventilation. Restriction of ventilation is exacerbated in the modern homes and buildings. As far as human dwellings are concerned the possible enhanced risk could be expected only in a rather small action of houses depending essentially on the building materials ventilation features and soil characteristics. These factors are directly responsible for enhanced input and subsequent stagnation of $\mathrm{Rn}-222$ in indoor air[1].

The solid state nuclear track detectors have been widely used for the measurement of radon levels in dwellings under different conditions many studies of radon concentration have been performed [2-6].

Solid state nuclear track detectors (CR39) were used in this work, to measure radon concentration in old buildings of Al-Najaf city. Thirty CR-39 detectors were distributed in old building in ten different locations in the city.

\section{Experimental Part}

A schematic diagram, for the technique used for long period indoor air radon measurement, is shown in Fig.(1). Each cup container is $5 \mathrm{~cm}$ height, $7 \mathrm{~cm}$ in diameter and contains $(1 \times 1) \mathrm{cm}$ square, thickness $(250 \mu \mathrm{m})$ of CR-39 nuclear track detector fixed with double sided adhesive tape to the bottom of the cup with its sensitive side upward [6]. The CR-39 detectors are capable of detecting alpha particles of all energies emitted from radon and its daughters. Alpha particles reaching the detector leave tracks, the number of which is proportional to the average radon concentration. The detectors were collected after approximately five months of exposure and were chemically etched to gather using $6.25 \mathrm{~N} \mathrm{NaCH}$ at $70^{\circ} \mathrm{C}$ for 12 hours. An optical microscope with magnification of $(10 \times 40)$ was used to count the number of tracks in each detector as shows in fig.(3).

The density of the tracks $(\rho)$ in the detectors was calculated according to relation [7].

Track density $\left(\rho\left(\right.\right.$ Tracks $\left./ \mathrm{cm}^{2}\right)=$

Average number of total pits (tracks)

\section{Area of field view}

Determination of indoor radon concentration (in unit $\mathrm{Bq} / \mathrm{m}^{3}$, since most regulatory reference are specified with this unit) with standard deviation (S.D.) are carried out by the following equations [8].

$$
\begin{aligned}
& C\left(\text { Bq. } m^{-3}\right)=\frac{C_{o}\left(\text { Bq. day } . m^{-3}\right)}{\rho_{o}\left(\text { Track. } . m^{-2}\right)}\left\{\frac{\rho\left(\text { Track } . \mathrm{Cm}^{-2}\right)}{t(\text { day })}\right\} \\
& \sigma_{n}(S . D .)=\sqrt{\frac{\sum_{i}^{n}\left(X_{i}-\bar{X}\right)^{2}}{n-1}}
\end{aligned}
$$

where:

$C:{ }^{222} \mathrm{Rn}$ concentration within the seals-cup air above the detector in $\left(\mathrm{Bq} / \mathrm{m}^{3}\right)$.

$C_{o}$ : The activity of standard sample in (Bq.day. $\mathrm{m}^{-3}$ ).

$\rho_{\mathrm{o}}$ : Track density (number of track. $\mathrm{cm}^{-2}$ ) on the detector, exposed to standard source.

$\rho$ : Track density (number of track. $\mathrm{cm}^{-2}$ ) of the detectors exposed to the samples under study. $t$ : Exposure time (days).

$\sigma_{n}($ S.D. ) : Standard deviation.

A number of detectors were exposed to a known dose of a standard radon source for a period of time. Then those dosimeters were collected and treated chemically (etching). The average numbers of tracks in $\mathrm{cm}^{-2}$ were observed. These detectors were considered as the calibration standard [9, $10]$.

A constant ( $\mathrm{k})$ can be defined as calibration constant which is :

$$
k=\frac{\rho_{o}\left(\text { Track.cm }{ }^{-2}\right)}{C_{o}\left(\text { Bq.d.cm }{ }^{-3}\right)}
$$

Writing this in eq.(2):

$$
C\left(B q \cdot m^{-3}\right)=\frac{1}{k}\left\{\frac{\rho}{t}\right\}
$$


where $\mathrm{k}$ : is called the calibration factor in terms of track. $\mathrm{cm}^{-2} / \mathrm{Bq} . \mathrm{d} . \mathrm{m}^{-3}$, or the calibration coefficient which was determined experimentally.

The calibration factor for dosimeters exposed for 40 days to Radium ${ }^{226} \mathrm{Ra}$ (Radon source) of activity $0.33 \times 10^{4}(\mathrm{~Bq})$ was calculated to be $\left(\frac{1}{k}=0.27 \pm 0.00335\right)$ [ (Bq. d. $\mathrm{m}^{-3}$ ) per $\left(\right.$ track. $\left.\left.\mathrm{cm}^{-2}\right)\right]$. The value is the same as that reported in many works [10-13] using the same calibration method.

$$
\left.\frac{1}{k}=0.2745 \text { (Bq.d. } \mathrm{m}^{-3} / \text { Track } . \mathrm{cm}^{-2}\right)
$$

Substituting the reversed calibration constant in equation (4):

$$
C_{a}\left(B q \cdot m^{-3}\right)=0.2745\left\{\frac{\rho}{t}\right\}
$$

This equation was used to determine the radon concentration in air in the present work.

The annual effective doses are derived by using Eq.(7) [14].

$D_{R n}=C_{R n}$ of $n D f_{R n}$

The dose conversion factors values $\left(\mathrm{Df}_{\mathrm{Rn}}\right)$ for indoor and outdoor which are used to calculate the annual effective dose for ${ }^{222} \mathrm{Rn}$ in the present study are 3.6 and 5.4 $(\mathrm{nSv} / \mathrm{h}) /\left(\mathrm{Bq} / \mathrm{m}^{3}\right)$ respectively

where: $D_{R n}$ is the annual effective dose from indoor ${ }^{222} \mathrm{Rn}$ exposure (mSv/year), $C_{R n}$ is the concentration of ${ }^{222} \mathrm{Rn}$ indoor air in $\mathrm{Bq} / \mathrm{m}^{3}$, of is the occupancy factor 7000 hours indoor [14].

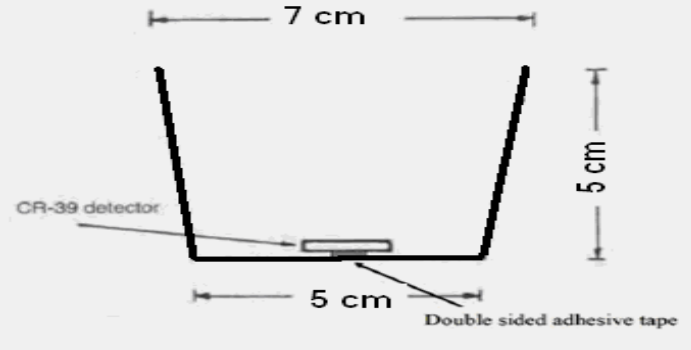

Fig.1: A schematic diagram of the sealed-cup technique.

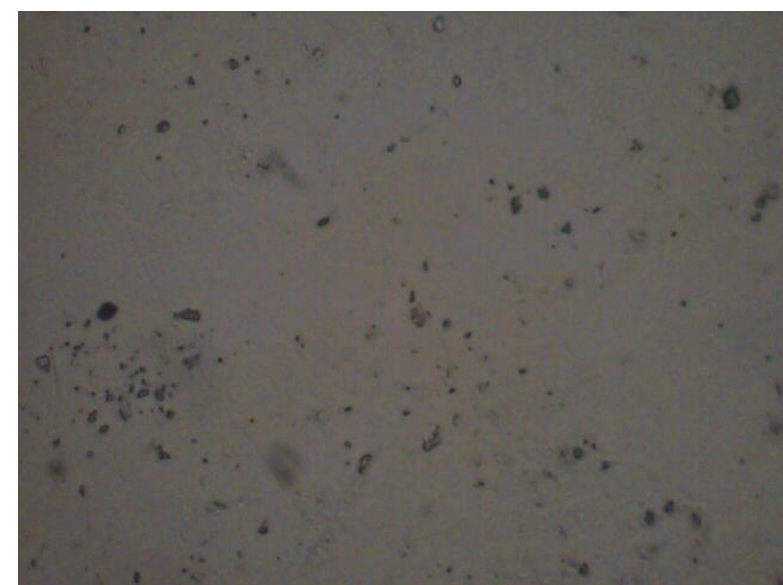

Fig. 2: Picture of track in Al.Wafaa sample.

\section{Results and Discussion}

The table and Fig.3 shows the measurements obtained, it includes minimum, maximum radon concentrations for different study areas in unit (Bq. $\left.{ }^{-3}\right)$, with the annual effective dose in $\left(\mathrm{mS} \cdot \mathrm{y}^{-1}\right)$.

From table, it can be seen that indoor radon concentrations varied from $53.61 \pm 8.777 \mathrm{~Bq} / \mathrm{m}^{3}$ in location Al.Wafaa sample to $11.654 \pm 4.216 \mathrm{~Bq} / \mathrm{m}^{3}$ in location Al.Moalmen sample in Al-Najaf government city. The observed variations of radon concentrations among various regions can be attributed to many factors like geological structure of the sites, the various types of building materials used for the construction of the houses, the heating systems and ventilation rates, and the aging effect on the building as well as the social habits of the dwellers.

The average ${ }^{222} \mathrm{Rn}$ concentrations indoors in Al-Najaf city are much lower than the recommended ICRP indoor concentration of radon (200-300) $\mathrm{Bq} / \mathrm{m}^{3}$ [15]. Comparing these results with those of some Arabic countries, the range of average radon concentration in Jordan (west of Iraq) buildings is $9.95-68.15 \mathrm{~Bq} / \mathrm{m}^{3}$ [16] and in some regions in Egypt, the average radon concentration in air of buildings was reported to be about $79.505 \mathrm{~Bq} / \mathrm{m}^{3}$ in range from $(38.62-120.39) \mathrm{Bq} / \mathrm{m}^{3}$ it can be seen 
that the values given in this paper are less[17].

The annual effective dose calculated using eq.(7) has the highest value at Al.Wafaa region of $\left(1.353 \mathrm{mSv}^{-1} \mathrm{y}^{-1}\right)$ which still it is less than those reported of $(3-10$ $\mathrm{mSv} . \mathrm{y}^{-1}$ ) [18].

\section{Conclusions}

1. The maximum allowed indoor concentration levels are between (200 300) $\mathrm{Bq} / \mathrm{m}^{3}$ as proposed by ICRP, therefore the results obtained in this study are less than the allowed concentration levels.

2. The maximum allowed annual effective dose indoor concentration levels are between $(3-10) \mathrm{mSv}_{\mathrm{y}} \mathrm{y}^{-1}[18]$, therefore the annual effective dose in buildings air of Al-Najaf city is less than the allowed maximum concentration level in buildings air.

Table 1: Radon concentration indoor of old building samples.

\begin{tabular}{|c|c|c|c|c|}
\hline \multirow{2}{*}{ Name of location } & \multicolumn{3}{|c|}{ Radon concentration in $\mathbf{( B q . \mathbf { m } ^ { - 3 } )}$} & \multirow{2}{*}{$\begin{array}{c}\text { Annual Effective } \\
\text { Dose }\left(\mathbf{m S . \mathbf { y } ^ { - 1 }}\right)\end{array}$} \\
\cline { 2 - 4 } & Min. & Max. & Mean & 0.676 \\
\hline Al.Motanaby & 18.647 & 32.633 & $26.805 \pm 4.919$ & 0.853 \\
\hline Al.Askary & 27.971 & 41.956 & $33.798 \pm 4.500$ & 0.383 \\
\hline Al.Jamhoriaa & 9.324 & 23.309 & $15.151 \pm 3.696$ & 0.471 \\
\hline Al.Shoarah & 13.985 & 23.309 & $18.647 \pm 3.442$ & 0.598 \\
\hline Messan 1 & 18.647 & 27.971 & $23.697 \pm 3.696$ & 1.353 \\
\hline Al.Wafaa & 41.956 & 69.927 & $53.611 \pm 8.777$ & 0.578 \\
\hline Al.Jazera & 13.985 & 41.956 & $22.920 \pm 8.990$ & 0.618 \\
\hline Al.Ameer & 13.985 & 41.956 & $24.474 \pm 7.470$ & 0.765 \\
\hline Al.Adala & 18.647 & 65.265 & $30.302 \pm 13.554$ & 0.2941 \\
\hline Al.Moalmen & 4.662 & 18.647 & $11.654 \pm 4.216$ & \\
\hline
\end{tabular}

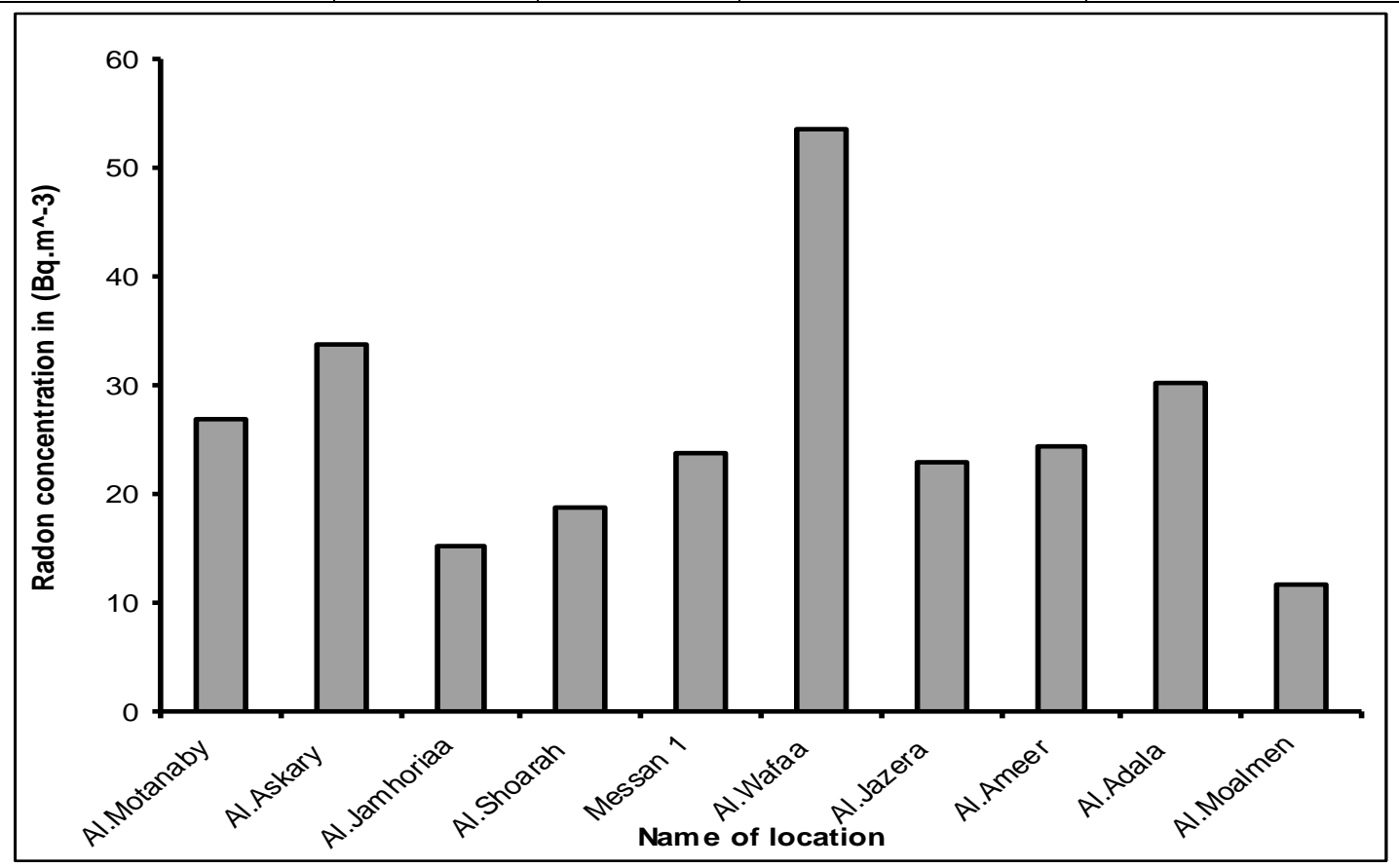

Fig.3: The average concentration of radon indoor of old building samples for study areas. 


\section{References}

[1] F. Michael, "Handbook of Radioactivity analysis", Elsevier Sci. (USA), Academic Press, $2^{\text {nd }}$. Ed., (2001) 20.

[2] R. Banjanac, A. Dragić, B. Grabež, D. Joković, D. Markushev, B. Panić, V. Udovičić, I. Aničin, Phys., Chem. and Tech., 4 (2006) 93-100.

[3] M. Abd El-Zaher and N.M.Fahmi , IX Radiat. Phys. and Prot. Conf., Nasr City Cairo, Egypt, (2008) 335-347.

[4] C. Németh, V. Jobbágy, N. Kávási, J. Somlai, T. Kovács, S.Tokonami, 'nukleonika, 55, 4 (2010) 459-462.

[5] K. Mamont, O. Stawarz, M. Karpińska, J. Kapała, K. Kozak, D. Grządziel, S. Chałupnik, I. Chmielewska, J. Olszewski, A. Przylibski, A.Żebrowski, Nukleonika, 55, 4 (2010) 589-593.

[6]F. K. Quashie, J. J. Fletcher, O.C. Oppon, A.B. Asumadu-Sakyi, D.A. Wordson, C.A. Adjei, E.O. Amartey and Paulina Amponsah, Research Journal of Envir. and Ear. Sci., 3, 1 (2011) 51-55.

[7] N. H. Custball, Amalds and G. A. Nielsen, Health Phys., 57, 6 (1989) 955-958.

[8] M. Al-Kofahi, B. Khader, A. Lehlooh, M. Kullab, K. Abumurad, and B.AlBataina, Nucl., Tracks Radiat. Meas., 20 (1992) 377-382.

[9] J.Wiegand, Envir. Geol., 40 (2001) 949963.

[10] M. Rasas, "Measurement of Radon and Its Daughter's Concentrations in Indoor and
Outdoor Throughout Gaza Strip", M. Sc. Thesis, Islamic University of Gaza, (2003).

[11] M. M. Al-Kofahl, "Measurement of Radon-222 in Jordanian Dwellings", M. Sc. Thesis, Physics Department, Yarmouk University, (1991).

[12] Y. S. Mayya, K. P. Eappen, K. S. V. Nambi, Radiat. Prot. Dosim., 77, 3 (1998) 177-184.

[13] M. Sersawi, "Study of the chronic radiation exposure situation in Gaza",(M. Sc. Thesis) Islamic University of Gaza in Physics, (2007).

[14] UNSCEAR (B), "Sources and Effects of Ionizing Radiation", Annex B: Exposures from Natural Radiation Sources. United Nation Scientific Committee on the Effect of Atomic Radiation, UNSCEAR, New York, USA (2000).

[15] ICRP "Protection against of ${ }^{222} \mathrm{Rn}$ at home and at work, publication 65, Annals of ICRP, (2011)

[16] B.Salameh, O. Abu-IIaija, W. Ajlouni and M. Abdelsalam, Research Jordan of Environmental Toxicology, 5 (2011) 71-75. [17] M. Abd El-Zaher\& N. M. Fahmib, Egypt IX Radiat. Phys. and Prot. Conference, Nasr City - Cairo, Egypt, (2008).

[18] A. Clouvas, S. Xanthos and M. Antonopoulos, Radiat. Prot. Dos.,1(2006) 9. 